\title{
Subsidized buyer credits: Atypical results in strategic trade theory
}

\author{
G.J. Stoelinga ${ }^{a}$, J.-M. Viaene ${ }^{a, b, *}$, L.T. Visscher ${ }^{a}$ \\ ${ }^{a}$ Department of Economics, Erasmus University H8-11, P.O. Box 1738, 3000 DR Rotterdam, Netherlands \\ ${ }^{\mathrm{b}}$ Tinbergen, Institute Rotterdam, Oostmaaslaan 950-952, 3063 DM Rotterdam, Netherlands
}

Received 16 March 1994; accepted 6 June 1994

\begin{abstract}
Using subsidized buyer credit as a policy tool, it is shown that the general result of strategic trade policy, namely that, by committing itself to an export subsidy, any government can favorably change the outcome of the Cournot oligopoly, does not necessarily hold.
\end{abstract}

Keywords: Buyer credit; Cournot-Nash equilibrium; subsidy

JEL classification: F13

\section{Introduction}

Since the introduction of imperfect competition into the theory of international trade, much attention has been focused on the discussion concerning optimal trade policy. Brander and Spencer (1985) first provided governments with a strong, unilateral incentive to engage in active trade policy. Their argument hinges on the concept of profit shifting, the idea that it is to the advantage of a country to capture a larger share of the production of profit-earning imperfectly competitive industries. The extension by Eaton and Grossman (1986) shows the role of oligopolistic conduct; export subsidies are effective when firms engage in Cournot competition, while export taxes are optimal when the international market is dominated by Bertrand behavior.

The policy tool envisaged by Brander and Spencer (1985) and Eaton and Grossman (1986) is, in essence, a production subsidy and therefore not specific to international trade. In contrast, subsidizing interest on buyer credit is a widely used policy instrument directly aimed

* Correspondence to: Jean-Marie Viaene, Department of Economics, Erasmus University H8-11, P.O. Box 1738, 3000 DR Rotterdam, Netherlands. 
at stimulating trade (OECD, 1990; Abraham, 1990). In this paper the question is raised whether the tenuous conclusions of strategic trade policy, repeatedly underlined and generally accepted [see, e.g. Dixit (1987), Krugman (1989)] are invariant with respect to the type of policy tool used.'

Subsidized buyer credits take the form of interest subsidies and arise whenever a foreign buyer is allowed to defer payment. An interest below the market rate is charged on a loan extended by an official export credit agency to a foreign importer in order to improve the relative position of a domestic firm. The financial resources spent on this type of subsidy are therefore transferred abroad. This raises the following question: are the costs of export subsidization by means of subsidized buyer credits fully recovered by the initiating country? Here, no definite answer can be given in contrast to production subsidies.

\section{A conjectural variation model}

In our model we will make the following standard assumptions. First, we will assume a duopoly, consisting of a domestic and a foreign company, producing imperfect substitutes for a third-country market. Label the firms and the corresponding countries by 1 (home) and 2 (foreign). Second, disregarding domestic consumption in the producer countries, we will assume that both goods are produced for exporting purposes only. Third, a constant unit cost $c$ is similar for both firms. Fourth, we will assume that every purchase made by the importing country is entirely bought on credit terms. Finally, only the domestic government is policy active. Foreign retaliation is considered in the next section. We denote third-country demand for home and foreign goods by $x_{1}$ and $x_{2}$ respectively, their price by $p_{1}$ and $p_{2}$, and the world lending rate by $i$.

The profits $\Pi_{j}$ of both firms are given by their revenue functions $R_{j}(\cdot)$ minus the production costs:

$$
\Pi_{j}=\left[R_{j}\left(x_{j}, x_{l}\right)-c x_{j}\right] \quad j=1,2 ; l=1,2 ; l \neq j .
$$

Each firm entertains a conjectured quantity response of its rival, suggesting the following set of conjectural-variation parameters:

$$
v_{j}=\mathrm{d} x_{l} / \mathrm{d} x_{j} \quad j=1,2 ; l=1,2 ; l \neq j .
$$

Following Dixit's (1987) method of notation, using a comma to separate the function label from the differentiation subscript - for example $\partial R_{1} / \partial x_{2}=R_{1,2}$ - the first-order conditions for profit maximization are:

$$
\begin{aligned}
& R_{1,1}+v_{1} R_{1,2}=c \\
& R_{2,2}+v_{2} R_{2,1}=c
\end{aligned}
$$

\footnotetext{
${ }^{1}$ Subsidized supplier credits and subsidized export insurance are other popular instruments actually used to promote trade. They can, however, be interpreted as a domestic production subsidy.
} 
The second-order conditions are assumed to be satisfied. Domestic surplus is defined as the profit of the domestic firm net of the subsidy:

$$
W_{1}=\Pi_{1}-\left(1-\beta_{1}\right)(1+i) R_{1}\left(x_{1}, x_{2}\right) \quad \text { with } 1 /(1+i) \leqslant \beta \leqslant 1
$$

The parameter $\beta_{1}$ in (5) expresses the attractive conditions that are attached to the loan. Without a subsidy the loan due from the importing country would amount to $(1+i) R_{1}$. The creditor country, however, does not charge the world lending rate. The domain of $\beta_{1}$ stretches from $1 /(1+i)$ to 1 , since the range for government policy is bounded by two extremes; a complete interest subsidy, $\beta_{1}=1 /(1+i)$, versus no subsidy at all, $\beta_{1}=1$. It is crucial to note that a lower value of $\beta_{1}$ corresponds to a higher subsidy. Total differentiation of Eq. (5) leads to:

$$
\mathrm{d} W_{1}=\left[R_{1,1} \mathrm{~d} x_{1}+R_{1,2} \mathrm{~d} x_{2}\right]\left[1-\left(1-\beta_{1}\right)(1+i)\right]-c \mathrm{~d} x_{1}+(1+i) R_{1} \mathrm{~d} \beta_{1} .
$$

The unilateral introduction of the domestic subsidy on buyer credit shifts firm 1's reaction function along firm 2's reaction curve. If we define $r_{2}=\mathrm{d} x_{2} / \mathrm{d} x_{1}$ as the slope of firm 2's reaction function and use the first-order conditions (3) and (4) we can rewrite Eq. (6) and evaluate this expression at $\beta_{1}=1$, the point of no subsidy:

$$
\frac{\partial W_{1}}{\partial \beta_{1}}=\left(r_{2}-v_{1}\right) R_{1,2} \frac{\partial x_{1}}{\partial \beta_{1}}+(1+i) R_{1} \gtreqless 0
$$

The term $\left(r_{2}-v_{1}\right)$, being the difference between the slope of the foreign firm's reaction function and the domestic firm's conjecture about the rival's response, is crucial in determining the sign of Eq. (7). The Bertrand model of price setting is captured by defining the conjectures appropriately: $v_{1}<0$ and $\left(r_{2}-v_{1}\right)>0$ (Kamien and Schwartz, 1983; Dixit, 1987, p. 347) and with the two firms producing substitutes, $R_{1,2}<0$. In addition, $\partial x_{1} / \partial \beta_{1}<0$. In this case $\partial W_{1} / \partial \beta_{1}>0$. Consequently, subsidization in a Bertrand environment will always have a negative impact on domestic surplus, this is in accordance with Eaton and Grossman (1986).

In the Cournot case, $v_{1}=0, r_{2}<0$. This leaves us with two terms in Eq. (7) with determinate, but opposite signs: $r_{2} R_{1,2} \partial x_{1} / \partial \beta_{1}<0$ while $R_{1}>0$. The conclusion therefore must be that the sign of $\partial W_{1} / \partial \beta_{1}$ cannot be unambiguously determined; subsidized buyer credits can either have a positive or non-positive effect on domestic surplus. This atypical result deviates from the unambiguous findings of both Brander and Spencer (1985) and Eaton and Grossman (1986), who agree that an export subsidy benefits the home country. To understand the difference in results, note that a production subsidy directly reduces the domestic firm's marginal cost, thus cancelling on the national aggregate, while a subsidized interest on buyer credit stimulates third-country demand for the domestic firm's product and comes as a cost to the active country as a whole.

\footnotetext{
${ }^{2}$ No discount rate is applied in (5) as it would blur the comparison with received theory. Proper discounting by the government would, however, require more information about the timing of costs and profits in the interval.
} 


\section{Sensitivity analysis with linear examples}

To illustrate further the result found above under Cournot-Nash competition, consider the following set of third-country demand equations for domestic and foreign goods:

$$
\begin{aligned}
& x_{1}=1-\beta_{1}(1+i) p_{1}+\alpha(1+i) p_{2} \\
& x_{2}=1-(1+i) p_{2}+\alpha \beta_{1}(1+i) p_{1}
\end{aligned}
$$

where $\alpha$ (with values $0<\alpha<1$ ) measures the substitutability between goods 1 and 2 in third-country consumption. The subsidy $\beta_{1}$ works directly on the price of good 1 as it is perceived by the third-country importer.

After solving for $p_{1}$ and $p_{2}$ from (8) and (9), the Cournot-Nash equilibrium solution (denoted by superscript $n$ ) and the following comparative statics derivatives are readily obtained:

$$
\begin{aligned}
& \frac{\partial x_{1}^{n}}{\partial \beta_{1}}=-\frac{2}{\alpha} \frac{\partial x_{2}^{n}}{\partial \beta_{1}}=\frac{-2 c(1+i)\left(1-\alpha^{2}\right)}{\left(4-\alpha^{2}\right)}<0 \\
& \frac{\partial p_{1}^{n}}{\partial \beta_{1}}=\frac{-1}{(2+\alpha) \beta_{1}^{2}}\left[\frac{1}{1+i}+\frac{c \alpha}{2-\alpha}\right]<0 \\
& \frac{\partial p_{2}^{n}}{\partial \beta_{1}}=\frac{c \alpha}{\left(4-\alpha^{2}\right)}>0
\end{aligned}
$$

The main observation from these results is that the absolute values of (11) to (12) are increasing in the marginal cost $c$. This is important for the interpretation of Fig. 1.

The relationship between the rate of subsidization and the domestic surplus is given by (5) with $\Pi_{1}=\left(p_{1}^{n}-c\right) x_{1}^{n}$. Taking the derivative of this expression with respect to $\beta_{1}$ :

$$
\frac{\partial W_{1}}{\partial \beta_{1}}=\left[1-\left(1-\beta_{1}\right)(1+i)\right]\left[p_{1}^{n} \frac{\partial x_{1}^{n}}{\partial \beta_{1}}+x_{1}^{n} \frac{\partial p_{1}^{n}}{\partial \beta_{1}}\right]-c \frac{\partial x_{1}^{n}}{\partial \beta_{1}}+(1+i) p_{1}^{n} x_{1}^{n} .
$$

Setting $\partial W_{1} / \partial \beta_{1}=0$, using (10) and (11), we obtain the optimal subsidy $\beta_{1}^{*}$ as a function of the parameters of the model, $\alpha, c$ and $i$. The optimal subsidy $\beta_{1}^{*}$ must be such that the increase in the firm's profit as a result of a marginal increase in subsidy is just offset by the resources loss to the government. The question is whether $\beta_{1}^{*}$ falls within or outside the closed interval $[1 /(1+i), 1]$. A value of $\beta_{1}^{*}>1$ would imply a capital tax as optimal policy whereas $\beta_{1}^{*}<1 /(1+i)$ would imply a price subsidy larger than the complete interest subsidy.

Suppose that the world lending rate is $7 \%(i=0.07)$. Because data on $\alpha$ and $c$ are poor and subject to errors, sensitivity analysis over a wide range of these two parameters is carried out. The results are reproduced in Fig. 1. Here, $\beta_{1}^{*}$ is drawn as a continuous function of $\alpha$ for five values of $c$ ranging from 0.5 to 2.5 . Unlike the existing literature, the optimal policy prescribed by Fig. 1 is not uniform; it depends upon the parameter constellations $(c, \alpha)$. Whatever $c$, from the lower end of the range of $\alpha(\alpha<0.53)$, no subsidized buyer credit is 


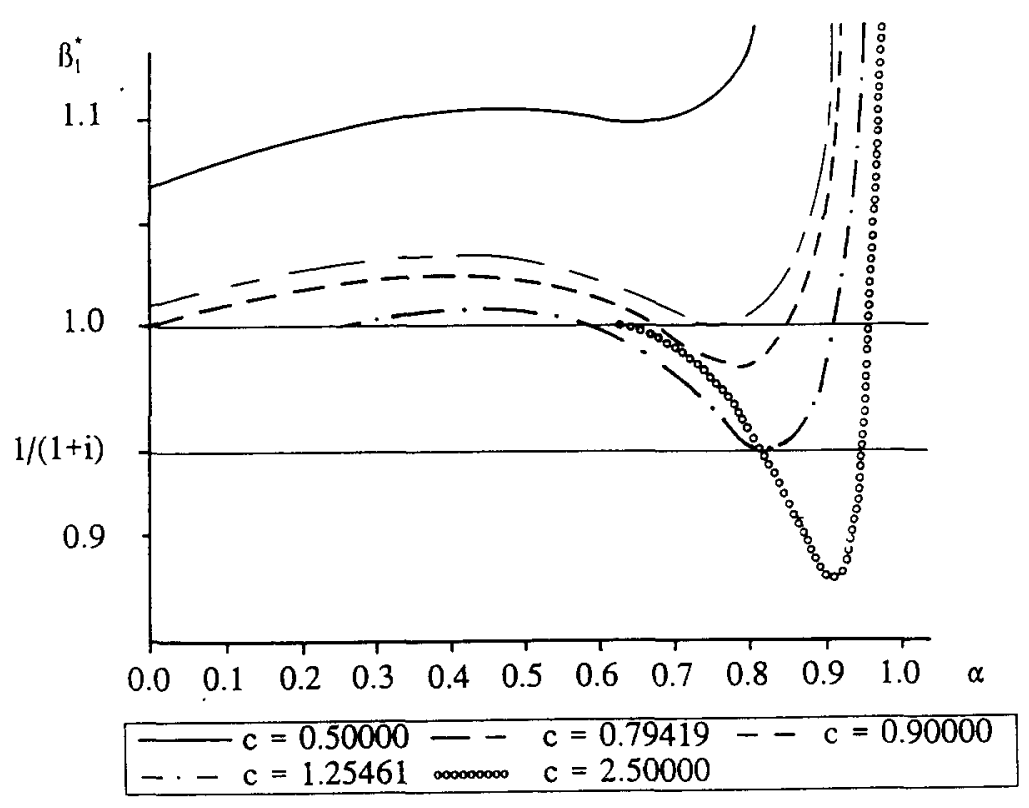

Fig. 1. Optimal interest subsidy $\beta_{1}^{*}$.

optimal. ${ }^{3}$ Charging a higher than world interest rate would even be justified. For the upper end of the range of $\alpha$-high cross-price effects - a subsidized buyer credit becomes justified for sufficiently high marginal costs $(c>0.794)$. For $c>1.255$, some combinations of $\alpha$ and $c$ call for a complete subsidized buyer credit. A price subsidy beyond the interest subsidy would also be justified.

It is possible to elaborate considerably on our model with foreign retaliation. In a two-stage export subsidy game, each country would chose, after the market stage, its export subsidy given the export subsidy of the other country so that $\partial W_{i} / \partial \beta_{i}=0(i=1,2) .{ }^{4}$ We can show by simulations that, for certain parameter values (e.g. $i=0.07, \alpha=0.7$ ), the equilibrium reaction functions in subsidies are upward sloping when $c<1.45$, vertical and horizontal lines when $c=1.45$, and downward sloping when $c>1.45$.

\section{Acknowledgements}

We are grateful to S. Goyal, D. Kovenock and seminar participants at the Tinbergen Institute for comments and suggestions.

\footnotetext{
${ }^{3}$ This could explain France's waste of resources in the promotion of its trade with former colonies using export credit subsidization (Messerlin, 1986).

${ }^{4}$ See Carmichael (1987) for the sequence of moves in a Bertrand-game. Our analysis could also be extended to account for foreign retaliation by using a dynamic export subsidy game with alternating moves with the governments and the firms as players. See Maskin and Tirole (1987) for details.
} 


\section{References}

Abraham, F., 1990, The effects on intra-community competition of export subsidies to third countries: The case of export credits, export insurance and official development assistance (Office for Official Publications (EC), Luxembourg).

Brander, J.A. and B.J. Spencer, 1985, Export subsidies and international market share rivalry, Journal of International Economics 18, 83-100.

Carmichael, C.M., 1987, The control of export credit subsidies and its welfare consequences, Journal of International Economics 23, 1-19.

Dixit, A., 1987, Strategic aspects of trade theory, in: T. Bewley, ed., Advances in economic theory: 5th world congress (Cambridge University Press, Cambridge) 329-362.

Eaton, J. and G.M. Grossman, 1986, Optimal trade and industrial policy under oligopoly, Quarterly Journal of Economics 101, 383-406.

Kamien, M.I. and N.L. Schwartz, 1983, Conjectural variations, Canadian Journal of Economics 16, 191-211.

Krugman, P.R., 1989, Industrial organization and international trade, in: R. Schmalensee and R.D. Willig, eds., Handbook of industrial organization, Vol. II (North Holland, Amsterdam) 1179-1223.

Maskin, E. and J. Tirole, 1987, A theory of dynamic oligopoly, III: Cournot competition, European Economic Review 31, 947-968.

Messerlin, P.A., 1986, Export-credit mercantilism à la Française, World Economy, Dec., 385-408.

OECD, 1990, Export credit financing systems in OECD member countries (OECD, Paris). 